The main events, which occurred on July 25 and August 2, 1946, are plotted in Figs. 1 and 2 respectively. The left-hand ordinate gives the measured solar radiation flux density in watts $/ \mathrm{cm} .{ }^{2} / \mathrm{c} . \mathrm{p} . \mathrm{s}$. band-width, and the right-hand ordinate the factor by which this exceeds the normal black-body radiation on this frequency. The very large surge of energy at 1624 U.T. On July 25 , which exceeded $10^{8}$ times black-body radiation, was followed by abnormally high noise throughout July 26-27, fluctuating between $6 \times 10^{-22}$ and $8 \times 10^{-25}$ watts $/ \mathrm{cm} .^{2} 7$ minimum value detectable by our apparatus except for occasional minimum value detectable by our apparatus except for occasional minor surges. Unfortunately, a prolonged thunderstorm began at 1200 U.T. on July 26 and caused disturbances which may have obscured some of the solar radiation maxima during the rest of that day. On August 2 three large surges were observed, each lasting for about two minutes. In the intervening periods between these surges the solar radiation was below the minimum detectable by our equip-
ment. These surges were plotted automatically by a pen recorder and their detailed structure is reproduced in Fig. 2. were recorded on July 22,24 and 25 . These are detailed in the accom-
panying table. No other significant increases of radiation were noticed panying table. No other significant increases of radiation were noticed continuous throughout the period, and the possibility that other surges occurred cannot therefore be excluded.

\begin{tabular}{|c|c|c|c|c|}
\hline Date & $\begin{array}{l}\text { Time } \\
\text { (U.T.) }\end{array}$ & Remarks & $\begin{array}{l}\text { Radiation ; } \\
\text { flux density } \\
\text { in watts/ } \\
\mathrm{em} .^{2} / \mathrm{c} . p . \mathrm{s} . \\
\text { band-width }\end{array}$ & $\begin{array}{c}\text { Ratio to } \\
\text { black-body } \\
\text { value }\end{array}$ \\
\hline July 22 & $1629-1642$ & Several surges & $5 \cdot 0 \times 10^{-24}$ & $7 \cdot 7 \times 10^{4}$ \\
\hline July 24 & 1628 & $\begin{array}{l}3 \text { surges each of } \\
\text { a few seconds } \\
\text { duration }\end{array}$ & $5 \cdot 0 \times 10^{-24}$ & $7 \cdot 7 \times 10^{4}$ \\
\hline July 25 & 1031.30 & $\begin{array}{l}\text { Surge approx. } \\
1 \text { sec. duration }\end{array}$ & $3.8 \times 10^{-23}$ & $5.8 \times 10^{5}$ \\
\hline "’ & 1032 & Syrge gnnrox & $3.8 \times 10^{-23}$ & $5.8 \times 10^{5}$ \\
\hline$"$ & 1434 & $\begin{array}{l}\text { surge approx. } \\
2 \text { sec. duration }\end{array}$ & $5.6 \times 10^{-23}$ & $8.6 \times 10^{5}$ \\
\hline " & 1435.30 & $\begin{array}{l}\text { Surge a pprox. } \\
0.5 \text { sec. duration }\end{array}$ & $5 \cdot 4 \times 10^{-24}$ & $8 \cdot 3 \times 10^{4}$ \\
\hline "’ & 1437.30 & , $\quad$, & $5 \cdot 4 \times 10^{-24}$ & $8.3 \times 10^{4}$ \\
\hline
\end{tabular}

The main event, beginning at 1624 U.T. on July 25, would appear to be closely associated with the intense solar flare which began at 1600 U.T. on that date and, according to Ellison ${ }^{4,5}$, reached its peak brilliance at about $1627 \mathrm{U} . \mathrm{T}$. The peak value in the solar energy of $1.3 \times 10^{8}$ times black-body value lasted from 1624 until 1627.30 U.T. Surges of almost identical magnitude associated with solar flares were found by Appleton and Hey during the large sunspot of February ated privately.

Physical Laboratories,

A. C. B. LOVELL

University of Manchester.

$$
\text { Aug } 16 .
$$

'Appleton, E. V., Nature, 156, 534 (1945).

2 Hey, J. S., Nature, 157, 47 (1946).

${ }^{3}$ Pawsey, J. L., Payne-Scott, R., and McCready, L. L., Nature, 157, $158(1946)$

Ellison, M. A., Nature, 158, 160 (1946).

$s$ Ellison, M. A., Nature, 158, 450 (1946).

\section{Use of Lead Sulphide Photo-conductive Cells for High-speed} Pyrometry

LEAD sulphide photo-conductive cells were first manufactured during the War in Germany by Gudden, Kaspar, Kutzscher and others, during the War in Germany by Gudden, Kaspar, Kutzscher and others,
though details have not yet been published. In late 1944 work on these cells was begun in Great Britain, and methods of manufacture were developed at the Admiralty Research Laboratory. This work were developed at the Admiralty Research Laboratory. This work will be described elsewhere. It is the purpose of this note to emphasize
the value of these detectors for the measurement of rapidly varying the value of these detectors for the measurement of rapidly varying
surface temperatures, a problem which often arises in physical and surface temperatures, a
engineering laboratories.

The cells are usually sensitive in the visible region of the spectrum, but the peak response lies in the infra-red region at $2 \cdot 7$ microns and
the long-wave threshold is near 3.5 microns. An average cell of area the long-wave threshold is near 3.5 microns. An average cell of area $10 \mathrm{sq} . \mathrm{mm}$., used at normal temperatures in conjunction with a radiation chopper and a tuned amplifier of response time 30 milliseconds, gives a signal equal to noise with $10^{-9}$ watts of radiation falling on it of wave-length between 1 and 3 microns. The response time can be decreased at the expense of sensitivity by increasing the ampliffer
band width. The response time of the cells themselves is of the order of 0.1 millisecond.

The radiation in the region 1-3 microns emitted by a black body at various temperatures is given below.

\begin{tabular}{|c|c|c|c|c|c|}
\hline Temp. ${ }^{\circ} \mathrm{C}$. & 100 & 200 & 400 & 600 & 800 \\
\hline $\begin{array}{c}\text { Watts/cm. } \\
\text { emitted } \\
(1-\%)\end{array}$ & $1.2 \times 10^{-2}$ & $2 \cdot 4 \times 16^{-3}$ & $7.9 \times 16^{-2}$ & $5 \cdot 5 \times 16^{-1}$ & $2 \cdot 35$ \\
\hline
\end{tabular}

It will be seen that there is sufficient radiant energy available for pyrometric measurements of reasonable accuracy at temperatures as
low as $100^{\circ} \mathrm{C}$. Surfaces which are not black will, of course, give correspondingly reduced signals, and constancy of surface conditions is required for accurate temperature measurement.

Cells made at the Admiralty Research Laboratory have been applied successfully to problems of this kind. In particular, the determination of temperature changes taking place along the circumference of a 36 -in. diameter railway wheel when subject to service braking from speeds up to $60 \mathrm{~m}$.p.h. is being made at Messrs. Ferodo Limited, on to the cell via Radiation from a $5 \mathrm{sq}$. mm. area of tyre falls on to the cell via an arrangement which comprises a water-cooled copper sighting-tube and a rotating slotted disk which serves as the radiation chopper. After amplification the signal is fed to one beam of a Cossor double beam C.R.O., while the other beam registers small angular deflexions of the wheel and a 50-cycle time trace. The amplifier employed, which was very kindly loaned by the Telecommunications Research Establishment, Malvern, has a response time film millisecond. Deflexions of the beams are recorded by a moving film camera and so give variations of the temperature along the tyre circumference as the wheel decelerates. Calibration is effected by focusing the cell on a small cylinder of tyre material contained in a optical paths and the surface condition of the metal.

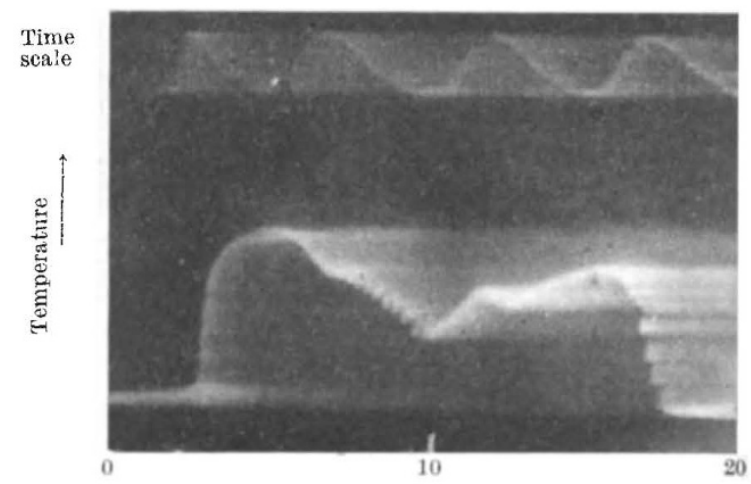

Distance along circumference (in.)

A short length from a typical record is shown in the accompanying figure. The maximum temperature in this example corresponds to about $400^{\circ} \mathrm{C}$., and it would appear that part or area viewed by the cell was in close contact with the brake for this limited period of the deceleration. In this equipment temperatures from $150 \mathrm{C}$. to 950 c. are covered in two ranges. The accuracy of measurement, which is determincd by the width of the trace, is between $5^{\circ} \mathrm{C}$. and $25^{\circ} \mathrm{C}$, depending on the range of temperature covered. The nature of the variations of temperature over the surface will be
discussed in a further publication.

Admiralty Research Laboratory,

E. LEE Teddington,
Middlesex.

Ferodo Research Laboratory,

R. C. PARKER Chapel-en-le-Frith.

\section{Absorption Spectrum of Trithioformaldehyde and Thiometaformaldehyde}

THE ultra-violet absorption spectrum of formaldehyde has been investigated by various workers and is now well known. In an attempt to investigate the corresponding spectrum of monomeric thioformaldehyde, the ultra-violet absorption of gaseous trithioformaldehyde and thiometaformaldehyde at temperatures up to $250^{\circ} \mathrm{C}$. has been examined. Using silica tubes up to $50 \mathrm{~cm}$. in length, no band spectrum was observed, absorption being continuous from $2739.5 \mathrm{~A}$. to the lower range of observation, the intensity and extension of the absorption increasing gradually with the temperature.

The ultra-violet absorption spectra of saturated solutions of trithioformaldehyde and thiometaformaldehyde in chloroform, ethyl alcohol, sulphuric ether and carbon tetrachloride did not show any dependence on the nature of the solute, except for chloroform in which the absorption of the trimer started at a somewhat higher wave-length than the absorption in the meta solution.

A detailed account will be published later.

M. Destrant

Institut de Chimie,

University of Liège.

Sept. 5 .

Feeble Paramagnetism of Hexavalent Chromium

FEEBLE paramagnetism ${ }^{1}$ is exhibited by certain ions in the ' $S$ state. As the spin quantum number in this case is zero, van Vleck ${ }^{2}$ suggested that there remains only the contribution of the highfrequency elements of the orbital moment, as given by the second term in the formula :

$$
X_{\mathrm{mol}}=-\frac{N c^{2}}{6 M c^{2}} \Sigma \bar{r}^{2}+\frac{2}{3} \underset{n^{\prime} \neq n}{N} \frac{\left|M^{0}\left(n^{\prime} ; n\right)\right|^{2}}{h \nu\left(n^{\prime} ; n\right)} .
$$

